(C) Middle East Institute. This article is for personal research only and may not be copied or distributed in any form without the permission of The Middle East Journal.

\title{
The Iraq War, Turkey, and Renewed Caspian Energy Prospects
}

\author{
Paul A. Williams and Ali Tekin
}

\begin{abstract}
Many have linked the US-led invasion of Iraq to its oil resources, leading some observers to question Caspian energy prospects. This article analyzes how the Iraqi occupation and Caspian oil prospects have been inter-linked, via the evolution of American and Turkish assessments of Iraq and the Caspian region. It shows that, contrary to initial expectations, the occupation of Iraq bolstered the Baku-Tbilisi-Ceyhan project as well as a number of other increasingly significant natural gas export pipelines.
\end{abstract}

$\mathbf{T}$ he March 2003 invasion of Iraq has been inextricably linked with that country's oil reserves, estimated to be the world's third largest after those of neighboring Saudi Arabia and Iran. ${ }^{1}$ It has been suggested, for example, that Iraq, under the influence of US-led occupation, would actively undermine OPEC's collective market power, serve growing US consumer demand for imported petroleum as well as corporate need for new investment opportunities, and even manipulate the flow of oil to China. ${ }^{2}$ American officials did little to dispel suspicions about US motives. As Baghdad fell, Vice President Dick Cheney claimed that Iraqi oil production could reach 3 million barrels per

Paul A. Williams is assistant professor in the Department of International Relations at Bilkent University. Recent publications include "Projections for the Geopolitical Economy of Oil after War in Iraq," Futures, Vol. 38, No. 9 (2006) and "Market Cycles, Power Politics and the Latest North-South Energy Trade Conflict," Third World Quarterly, Vol. 28, No. 1 (2007). He is also author of several forthcoming publications, including "New Configuration or Reconfiguration? Conflict in North-South Energy Trade Relations," in Rafael Reuveny and William Thompson, eds., North and South in the World Political Economy (London: Wiley-Blackwell, 2008); and, with Ali Tekin, "Turkey and EU Energy Security: The Pipeline Connection," East European Quarterly, Vol. 42, No. 2 (2008) and "Europe's External Energy Policy and Turkey's Accession Process," Europe-Asia Studies (2008). Ali Tekin is assistant professor and Jean Monnet Chair in the Department of International Relations at Bilkent University. Recent publications include "Future of TurkeyEU Relations: A Civilisational Approach,” Futures, Vol. 37, No. 4 (May 2005); “Turkey's Aborted Attempt at Export-led Growth Strategy: Anatomy of the 1970 Economic Reform," Middle Eastern Studies, Vol. 4, No. 1 (January 2006); and, with Iva Walterova, "Turkey's Geopolitical Role: The Energy Angle," Middle East Policy, Vol. 14, No. 4 (Spring 2007) and "The Europeanization of Turkish Foreign Policy towards the Middle East," in Nimrod Goran and Amikam Nachmani, eds., The Importance of Being European: Turkey, the EU and the Middle East (Jerusalem: The Hebrew University of Jerusalem, 2007).

1. Iraq ranks fourth if oil sands are factored into Canada's reserve portfolio, as indicated in BP Statistical Review of World Energy June 2007, p. 6. Given the relatively lesser extent of field exploration there, however, Iraq may hold 160-215 billion barrels of oil, with the estimated lower limit placing it behind both Canada and Saudi Arabia and the upper limit leaving it second only to Saudi Arabia. See United States Energy Information Administration (USEIA), Country Analysis Brief: Iraq, August 2007, http://www.eia.doe.gov/emeu/cabs/Iraq/Full.html.

2. See Neela Banerjee, "With the War Largely Over, OPEC Fears Oil Price Drop," The New York Times, April 21, 2003; Ian Rutledge, Addicted to Oil: America's Relentless Quest for Energy Security (London and New York: I.B. Tauris, 2005), pp. 178-201; and Walden Bello, "The Capitalist Conjuncture: over-accumulation, financial crises, and the retreat from globalization," Third World Quarterly, Vol. 27, No. 8 (2006), p. 1361. 
day by the year's end, while Deputy Defense Secretary Paul Wolfowitz told the US House Appropriations Committee that " $[t]$ he oil revenues of that country could bring between $\$ 50$ billion and $\$ 100$ billion over the course of the next two or three years."

Given these assumptions of Iraq's oil prowess, doubts about Caspian energy resurfaced. More specifically, would Iraqi oil obviate the need to transport higher-cost sources from landlocked Azerbaijan (and possibly Kazakhstan) to world markets via the Baku-Tbilisi-Ceyhan (BTC) pipeline reaching Turkey's Mediterranean coast? Indeed, as participants at a post-invasion conference on Caspian oil and gas in Istanbul expressed, "the prospect of expanded access to Iraqi energy reserves could cause investors to reconsider relatively expensive Caspian off-shore projects and the construction of the lengthy BTC route." 4

In reality, just the opposite has transpired. Great expectations for Iraqi oil remain slow to materialize, while the BTC pipeline is operational, providing both a valuable alternative outlet for Azerbaijan's crude oil and a small but significant addition to global supplies. ${ }^{5}$ Although the BTC had registered some progress before the invasion of Iraq, prolonged damage to Iraq's oil infrastructure under the occupation and the effects of disrepair and sabotage, albeit marginal, on world energy markets virtually guaranteed the economic viability not only of the BTC pipeline, but also of its twin Baku-TbilisiErzurum (BTE) or South Caucasus gas pipeline, which also conveys Azerbaijan's gas to Turkey. The seller's market has even brought the Nabucco pipeline, a vastly more complex undertaking to transport Caspian and Middle Eastern natural gas supplies to Europe through Turkey, into the realm of the feasible. These accomplishments seem remarkable in light of the fact that the seminal BTC pipeline was nearly shelved after the price collapse in 1998 and the downgrading of Azerbaijan's offshore oil-reserve estimates.

Initial US support for BTC was primarily political rather than financial. Despite favorable rhetoric from members of the Clinton Administration, the American government remained largely noncommittal towards funding the BTC, even as a means of breaking Russian control over the Caucasus transport corridor. Rather, Washington did more to back the project by maintaining its ban on the building of new pipelines from and through Iran. The occupation of Iraq inadvertently imparted a new momentum to Caspian projects like the BTC and BTE by helping to ratchet up world energy prices.

The aforementioned conditions also fed Turkey's interest in completing these projects. Prolonged constraints on Iraqi oil production and exports through the IraqTurkey (IT) crude oil pipeline, combined with elevated world oil demand, not only improved the commercial rationale of the BTC and BTE pipelines, but also dampened Ankara's initial expectations that Turkey might obtain higher oil transit revenues and

3. Jeff Gerth, "Report Offered Bleak Outlook About Iraq Oil," The New York Times, October 5, 2003.

4. Ariel Cohen, "Istanbul Conference: Quiet Concern Over Baku-Tbilisi-Ceyhan Pipeline's Fate," June 2, 2003, http://www.eurasia.org/departments/business/articles/eav060203.shtml.

5. In 2007, its first full year of operation, the BTC pipeline transported four-fifths of Azerbaijan's total oil exports and two-thirds of its output: "the largest contributor to non-OPEC supply growth in 2006 and 2007," as noted in USEIA, Country Analysis Brief: Azerbaijan, November 2007, http:// www.eia.doe.gov/emeu.cabs/Azerbaijan/Full.html. See also BOTAS, "Crude Oil Transportation Activities and Facilities," http://www.botas.gov.tr/eng/activities/crudeoil.asp. 
other economic benefits from restored trade with Iraq. Moreover, as compared to the IT pipeline, which began its tentative return to pre-invasion operational capacity only in the latter part of 2007, the siting and design of the BTC and BTE projects consciously attended to minimizing the risks of sabotage.

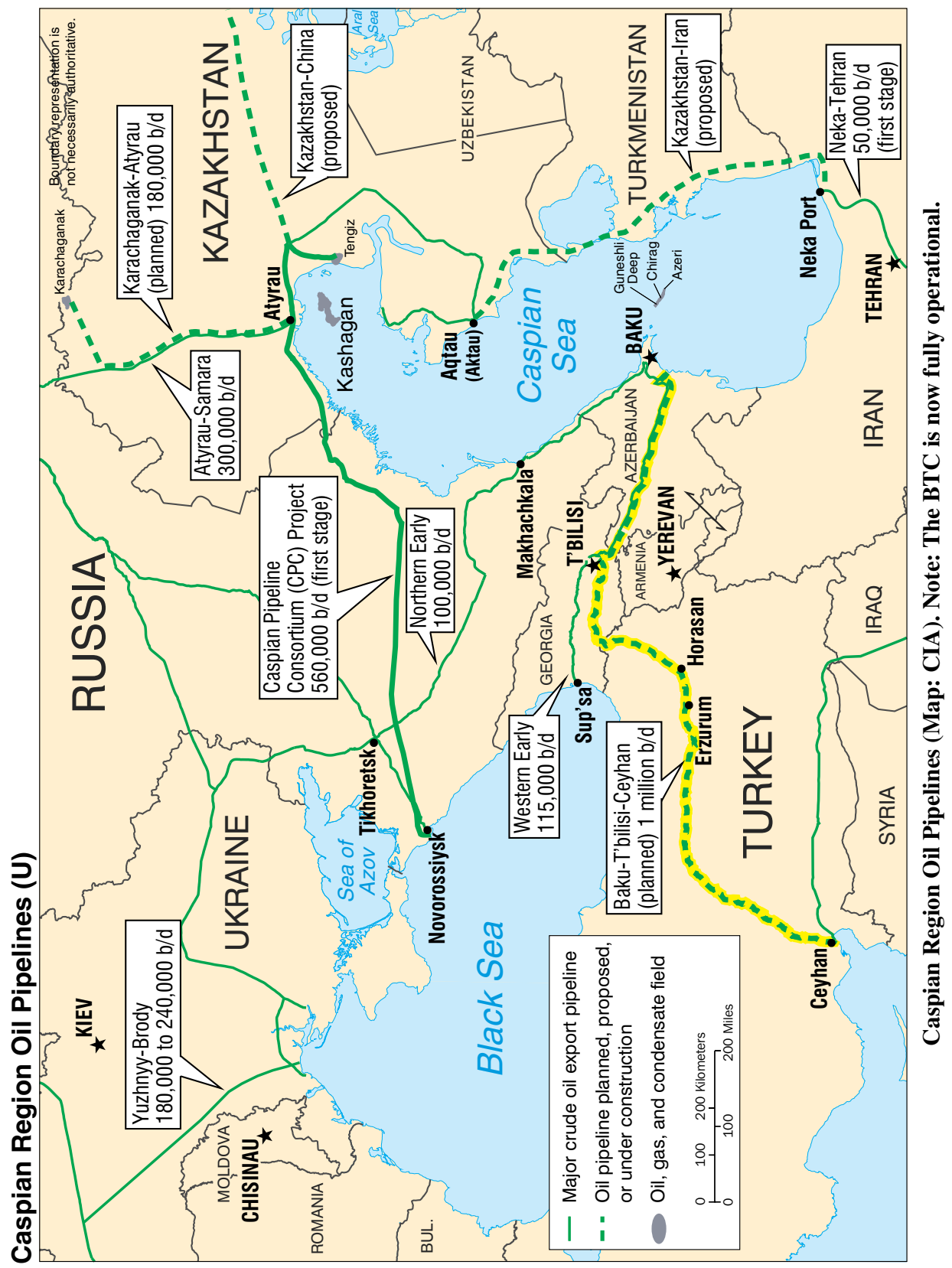


The next section focuses on the major obstacles that Caspian energy, primarily the BTC project, faced. The third section addresses factors that aided the success of this project, including America's Middle East policy, specifically towards Iraq and Iran. The fourth section examines how the US-led occupation of Iraq reshaped Turkey's energy transport policies. The fifth section broadens the scope of analysis to include natural gas, with a discussion of the links between the war in Iraq and Turkish, European, and American pipeline policies in both the Middle East and Caspian regions. The final section provides concluding remarks.

\section{OBSTACLES TO CASPIAN OIL EXPORTS}

First propounded by Bill Clinton and continued under the George W. Bush Administration, the US government's professed aim of consolidating democracy and market economies in the countries of the Former Soviet Union (FSU) featured a salient focus on developing the hydrocarbon production and export capacities of the non-Russian FSU part of the Caspian Sea region. Administration officials knew that Russia's estimated 148 billion barrels of potential oil reserves were one-third larger than those of the other FSU Caspian countries and that Russia had nearly nine times as much gas. ${ }^{6}$ Nonetheless, greater perceived opportunities for foreign companies to gain access to the non-OPEC hydrocarbon deposits of Azerbaijan (Baku), Kazakhstan (Astana), and Turkmenistan (Ashgabat) and to build new export infrastructure through Georgia (Tbilisi), Turkey (Ankara), and Ukraine (Kiev), thus creating new export routes and revenues free from Moscow's control, made the Caspian integral to Clinton's vision. ${ }^{7}$ In ranking his administration's pipeline aid criteria, Jan Kalicki mentioned the Caspian states' "independence, sovereignty and prosperity," "democratic and free-market development," and "regional cooperation and conflict resolution" prior to citing diversified energy sources and assistance for US commercial pursuits. ${ }^{8}$ This lent itself to the perception that Washington was using commercial interests to realize geopolitical objectives. ${ }^{9}$

The United States' advocacy of 'multiple pipelines' primarily targeted Moscow's jurisdictional dominance over the egress of Caspian energy supplies. Even in the 1990s, when energy markets were relatively soft, Russia constituted a difficult place to invest - to a lesser extent in terms of exploration and production (E\&P), but to a larger extent in relation to building new pipelines independent not only of Gazprom, the state-run producer of most Russian gas and the monopoly operator of trans-Russian pipelines, but also of Transneft, the sole government-owned oil pipeline operator. This leverage has permitted Moscow to use pipeline export quotas as a means of coercing

6. Jan Kalicki, "Caspian Energy at the Crossroads," Foreign Affairs, Vol. 80, No. 5 (September/ October 2001), p. 123.

7. Gawdat Bahgat, "Pipeline Diplomacy: The Geopolitics of the Caspian Sea Region," International Studies Perspectives, Vol. 3, No. 3 (August 2002), p. 311.

8. Jan Kalicki, "U.S. Policy in the Caspian: Pipelines, Partnership and Prosperity," Middle East Policy, Vol. 6, No. 2 (October 1998), pp. 146-147.

9. Julia Nanay, "The U.S. in the Caspian: The Divergence of Political and Commercial Interests," Middle East Policy, Vol. 6, No. 2 (October 1998), p. 156; David L. Goldwyn, Martha Brill Olcott, Julia Nanay, and Thomas Stauffer, "Symposium: The Caspian Region and the New Great Powers," Middle East Policy, Vol. 7, No. 4 (October 2000), p. 12. 
private companies to pay their debts or sell off assets. ${ }^{10}$ Indeed, the plans of the domestic private firm Yukos to build private pipelines to export oil to the United States and China may have precipitated the October 2003 arrest of company head Mikhail Khodorkovsky (allegedly for non-payment of back taxes), followed by Yukos' sale to Gazprom's oil subsidiary Rosneft and the rescinding of American firms' exploration rights to an offshore Sakhalin Island oilfield. ${ }^{11}$

Yet, it was precisely Moscow's control over access to the Russian upstream sector and FSU export routes that counseled prudence on the part of US policymakers in carrying out the 'multiple pipelines' policy. As David Goldwyn, then an energy official with the Clinton Administration, remarked in 2000, "We want Russia to resume its role as an oil power because it's important for supply, for Russia's democracy and for its development." 12 Washington backed the building of a 1,600-kilometer (km) pipeline (not majority controlled by Transneft, but still traversing Russian territory) that started transporting oil from Kazakhstan's Tengiz field to Russia's Black Sea port of Novorossiysk in 2001. This support was partially rooted in the fact that the American firms Chevron and ExxonMobil owned nearly a combined one-quarter of the Caspian Pipeline Consortium (CPC) as well as three-quarters of the Tengiz oil stock that feeds the CPC pipeline (which also began receiving oil from Kazakhstan's Karachaganak field, one-fifth owned by Chevron as well).$^{13}$ Moreover, even after the case against Yukos' chairman had gotten underway and Chevron and ExxonMobil had lost the rights to explore for Sakhalin Island oil, the latter were seeking to access Russia's Shtokman field and export its liquefied natural gas (LNG) to the United States, a project then being considered for financial assistance from the US Export-Import Bank and Overseas Private Investment Corporation. ${ }^{14}$

Until 2002, when this ban was fully waived as a reward for Baku's counter-terrorism efforts, Washington even maintained economic sanctions on Azerbaijan for its blockade of the Armenian territories of Yerevan and Nagorno-Karabakh. This policy, together with the US sanctions against Iran, forced Caspian hydrocarbon producers into

10. "New rules cause trouble to Russian oil companies," Alexander's Gas \& Oil Connections (AGOC), August 31, 1998, http://www.gasandoil.com/goc/news/ntr83607.htm.

11. Alex Rodriguez, "Moscow's interest in US-Russian oil partnership is fading fast," $A G O C$, March 25, 2004, http://www.gasandoil.com/goc/news/ntr41206.htm; Marshall Goldman, "Putin and the Oligarchs," Foreign Affairs, Vol. 83, No. 6 (November/December 2004).

12. Goldwyn et al, "Symposium," p. 4.

13. Transneft's share is roughly one-quarter as well, and the Kremlin's control over this consortium partner played a role in pressuring the CPC to accept a 25\% transit tariff hike in late 2007 and to agree to send incremental volumes of oil through the Bourgas-Alexandroupolis pipeline (a joint venture of the Italian company ENI and Transneft to build a Bosporus bypass route), in exchange for assenting to expand the CPC pipeline. See Vladimir Socor, "Western Majors Sign Agreement on Intent on Trans-Caspian Oil Transport System," Eurasia Daily Monitor, January 25, 2007, http://www. jamestown.org/edm/article.php?article_id=2371838; USEIA, Country Analysis Brief: Kazakhstan, February 2008, http://www.eia.doe/emeu/cabs/Kazakhstan/pdf.pdf; "Russia: The Putin Doctrine," Energy Compass, January 4, 2008, http://global.factiva.com/ha/default.aspx.

14. Kalicki, "U.S. Policy in the Caspian," p. 148; "US concerned about negative trends in Russia's oil industry," AGOC, June 29, 2004, http://www.gasandoil.com/goc/news/ntr42699.htm; and "Russian atmosphere hard for Western companies," AGOC, October 14, 2004, http://www.gasandoil.com/ goc/company/cnr44173.htm. 
a greater dependence on Russian export routes. ${ }^{15}$ Only in early 1999, when a lowercapacity 'western' pipeline was completed to transport 'early' Azeri-Chirag-Guneshli (ACG) oil from Baku and the Georgian port of Supsa, did Azerbaijan obtain an alternative to the 'northern' pipeline between Baku and Novorossiysk, which was vulnerable to sabotage and oil theft along its Chechnyan section as well as chronic disputes over the division of transit fees between Chechnya and Russia. ${ }^{16}$

By the early $21^{\text {st }}$ century, Caspian energy projects could hardly survive on geopolitical credentials alone. Economic conditions were inauspicious: getting offshore Caspian oil to Western markets was estimated to require a price threshold of at least $\$ 10$ per barrel, ${ }^{17}$ which had collapsed briefly when OPEC's output hike coincided with a slackening in Asian demand. More specifically, the BTC project had its own intrinsic problems. One consisted of disputes over transit fees and financial guarantees pitting Baku and the British Petroleum (BP)-led 12-company Azerbaijan International Oil Consortium (AIOC) against Ankara. Another problem ensued from a series of unsuccessful drillings, which led AIOC to downgrade estimates of offshore ACG oil reserves (the main feeder source for the BTC pipeline) to 3 billion barrels, half of what had been assessed earlier as necessary to justify BTC's fixed costs, and postpone estimated maximum oil production of 800,000 barrels until 2007, two years after the project's planned completion. ${ }^{18}$

Therefore, it was expected that the BTC's viability would depend to a greater extent on obtaining Kazakhstan's oil. It was envisaged that the extant BTC line, crossing nearly $1,800 \mathrm{~km}$ from the Caspian's western littoral to the Mediterranean, would be extended another one-third of that distance eastwards to reach Aktau on Kazakhstan's coast, forming a longer ABTC energy corridor. Exacerbating the already difficult topography of the BTC route, a trans-Caspian subsea pipeline would add further geological risks. ${ }^{19}$ Moreover, the Caspian Sea's own geopolitical contours, incorporating the territorial presence of Russia

15. Goldwyn et al, "Consortium," pp. 4, 6; and Baghat, "Pipeline Diplomacy," pp. 321-322.

16. "Azeri oil arriving in Novorosiisk," AGOC, December 8, 1997, http://www.gasandoil.com/goc/ news/ntr75049.htm; "First 'early Caspian oil' in tanker at Supsa to European markets," AGOC, May 11, 1999, http://www.gasandoil.com/goc/news/ntr92002.htm; USEIA, Country Analysis Brief: Azerbaijan; Jennifer DeLay, "Shutdown of Baku-Novorosiisk shows Russia has a lot of work to do on pipeline security," AGOC, August 6, 1999, http://www.gasandoil.com/goc/news/ntr93274.htm; and "Headaches for Russian oil export," AGOC, September 8, 1999, http://www.gasandoil.com/goc/news/ntr93784.htm.

17. Amy Meyers Jaffe and Robert A. Manning, "The Myth of the Caspian 'Great Game': The Real Geopolitics of Energy," Survival, Vol. 40, No. 4 (Winter 1998-99), p. 118; and Fadhil J. Chalabi, "Gulf Oil vs. the Oil of the Caspian Sea," in The Emirates Center for Strategic Studies and Research, Caspian Energy Resources: Implications for the Arab Gulf (Abu Dhabi: The Emirates Center for Strategic Studies and Research, 2000), p. 162.

18. "Baku-Ceyhan pipeline needs to be cheaper to be attractive," AGOC, December 24, 1998, http://www.gasandoil.com/goc/news/ntc85246.htm; Jennifer DeLay, "Azerbaijani, Turkish working groups butt heads over Baku-Ceyhan costs and tariffs," AGOC, September 22, 1999, http://www.gasandoil.com/goc/news/ntc93973.htm; and Charles Coe, "Questions still hover over pipeline projects following Richardson's Caspian tour," AGOC, October 15, 1999, http://gasandoil.com/goc.news/ ntc94208.htm. As of late 2007, maximum Azeri oil output was forecast to reach 1.3 million daily barrels by 2010, most of which would come from the feeder source for the BTC pipeline, as noted in USEIA, Country Analysis Brief: Azerbaijan.

19. On Caspian Sea geology, see Philip D. Rabinowitz, Mehdi Z. Yusifov, Jessica Arnoldi, and Eyal Hakim, "Geology, Oil and Gas Potential, Pipelines, and the Geopolitics of the Caspian Sea Region," Ocean Development \& International Law, Vol. 35 (2004), pp. 19-40, especially pp. 31-33. 
and Iran as littoral states, have been as daunting as the myriad separatist conflicts afflicting the trans-Caucasus and Turkish legs of the BTC project. The latter states maintain a common opposition to deeper US inroads into the basin region. ${ }^{20}$ However, Moscow did agree with Astana in 1998 and Baku in 2001 to demarcate national offshore sectors based on partitioning the seabed equidistant to opposite shores, while Tehran has long favored either a 'condominium approach' (joint management) or an equal five-way division of the surface area and seabed resources. ${ }^{21}$ Iran even used military force to destroy Azerbaijan's boundary-demarcation buoys in the 1990s and to halt BP's exploratory drilling in a disputed block in July 2001. ${ }^{22}$ Moreover, the aforementioned CPC undertaking would lessen the necessity for an ABTC pipeline. Consequently, plans for an ABTC route have been limited to increasing tanker shipments of Kazakh oil. ${ }^{23}$

\section{MULTIPLE LIFELINES FOR CASPIAN OIL}

Renewed interest in the Caspian, notably the BTC, had several direct sources. Energy prices already had begun firming up upon the post-1999 resumption of rising Chinese oil consumption (which increased by half over 1999-2004, accounting for nearly one-third of the global increase) and crude oil imports (which increased more than six-fold between 1998, when they provided 6\% of Chinese supply, and 2004, when they hit $30 \%){ }^{24}$ The BTC pipeline also was aided by favorable developments particular to the project itself. These included such fortuitous events as the 1999 discovery that Azerbaijan's offshore Shah Deniz field held large gas deposits, which started to reach Turkey in 2007 via the South Caucasus Pipeline running parallel to the BTC; AIOC's upward revision of estimated ACG oil reserves to 5.3 billion barrels, above the breakeven point; and post-1999 cooperation among Baku, Tbilisi, Ankara, the Main Export Pipeline (MEP) company (which includes the AIOC), and various outside financiers on tariff levels, transit-revenue allocations, and pipeline-cost defrayments. ${ }^{25}$

Notwithstanding its 'multiple pipelines' policy, the US government's role in up-

20. Bahgat, "Pipeline Diplomacy," p. 318.

21. Gawdat Bahgat, "Energy Security: The Caspian Sea," Minerals \& Energy, Vol. 2, No. 2 (2005), pp. 3-15, especially pp. 6-8.

22. Rabinowitz et al, "Geology, Oil, and Gas Pipelines, and the Geopolitics of the Caspian Sea Region," pp. 31-32; Robert M. Cutler, "Renewed conflicts in the Caspian: Part 1," AGOC, September 11, 2001, http://www.gasandoil.com/goc/news/ntc13757.htm; and "Flare-up of tension between Tehran and Baku is not only about oil," AGOC, September 25, 2001, http://www.gasandoil.com/goc/news/ntc13971.htm.

23. This is indicated by AIOC's 2006 announcement of plans to reduce the amount of its oil (from the ACG reserves) to $60 \%$ of the BTC pipeline's throughput. See USEIA, Country Analysis Brief: Azerbaijan.

24. Paul A. Williams, "Projections for the geopolitical economy of oil after war in Iraq," Futures, Vol. 38, No. 9 (November 2006), p. 1080. Chinese import statistics are derived from data contained in various issues of the International Energy Agency's (IEA) Oil Market Report, http://omrpublic.iea.org.

25. Robert M. Cutler, "Just when you thought Baku-Ceyhan was dead and buried: Part I," AGOC, December 24, 1999, http://www.gasandoil.com/goc/news/ntc95244.htm; Robert M. Cutler, "Just when you thought Baku-Ceyhan was dead and buried: Part 6," AGOC, May 12, 2000, http://www. gasandoil.com/goc/news/ntc01943.htm; Robert M. Cuter, "Just when you thought Baku-Ceyhan was dead and buried: Part 7, conclusion," AGOC, May 26, 2000, http://www.gasandoil.com/goc/news/ ntc02156.htm; and "Financiers and investors line up behind the BTC project," AGOC, June 27, 2002, http://www.gasandoil.com/goc/news/ntc22653.htm. 
grading Caspian energy output and export prospects was more indirect. A constant degree of interest in non-Russian FSU projects relates to Washington's bans on US and other financing of Iranian energy projects. A natural lure for foreign investment, Iran has a pipeline network that can be extended from its Caspian shore to the Strait of Hormuz, potentially undercutting the economic rationale for trans-Turkish routes, and 9 and $13 \%$ of global oil and natural gas reserves, respectively (in 1995). ${ }^{26}$ However, since 1995 , US firms have been barred from investing in Iranian energy projects and Congress' 1996 Iran-Libya Sanctions Act (ILSA, amended in 2006 to the Iran Sanctions Act, valid through 2011) has sanctioned foreign investment in Iran of over \$20 million per year. ${ }^{27}$ While US firms were denied licenses to 'swap' Caspian Sea oil with Iran, the ILSA was waived in accordance with the Clinton Administration's May 1998 approval of a FrenchRussian-Malaysian project to develop the South Pars gas field, so US companies felt disadvantaged against foreign firms. ${ }^{28}$ While US companies seemed to be stalling on the BTC project in anticipation of the expiry of sanctions on Iran, prohibitions on Iranian pipeline investment held firm. ${ }^{29}$ Moreover, during 1997-2002, while OPEC exports decreased 7\%, Iran's fell by one-fifth, and the seller's market of 2002-2006, during which OPEC exports rose by one-quarter, boosted Iranian volumes by only $12 \% .{ }^{30}$

Post-9/11 support for democratization, counter-terrorism, and weapons non-proliferation within the scope of President Bush's 'Greater Middle East Project' finally ended prohibitions on US aid to Azerbaijan. Conversely, this campaign, by furnishing a new rationale for efforts to unseat Saddam Husayn in Iraq, foreshadowed a lowering of oil prices that threatened the commercial viability of non-Russian FSU energy projects. Inadvertently, however, the occupation of Iraq boosted Caspian energy plans, helping to raise prices and Turkey's interest in hosting alternative energy transit routes, by inciting a sabotage campaign against that country's oil infrastructure, already dilapidated from decades of warfare and UN sanctions.

Iraq had been under UN Security Council sanctions since the end of the 1990-

26. Goldwyn et al, "Symposium," p. 14; Organization of Petroleum Exporting Countries (OPEC), OPEC Annual Statistical Bulletin 2006, pp. 17-20, http://www.opec.org/library/Annual\%20Statistica 1\%20Bulletin/pdf/ASB2006.pdf. Iran was estimated to possess over 11 and 15\%, respectively, of the world's total oil and gas reserves in 2006, according to BP Statistical Review of World Energy June 2007, pp. 6 and 22.

27. Kalicki, "Caspian Energy," pp. 126-127; and Kenneth Katzman, Iran: U.S. Concerns and Policy Responses (Washington, DC: Congressional Research Service, 2007), pp. 46-49, http://fpc.state. gov/documents/organization/91002.pdf.

28. Katzman, Iran: U.S. Concerns and Policy Responses, p. 47; House of Representatives, Hearing before the Subcommittee on the Middle East and Central Asia of the Committee on International Relations, One Hundred Eighth Congress, First Session, June 25, 2003, Enforcement of the Iran-Libya Sanctions Act and Increasing Security Threats from Iran (Washington, DC: US Government Printing Office, 2003); and Fiona Hill, "Pipelines in the Caspian: Catalyst or Cure-all?" Georgetown Journal of International Affairs, Vol. 5, No. 2 (Winter/Spring 2004), pp. 19, 21.

29. Robert M. Cutler, "Just when you thought Baku-Ceyhan was dead and buried IV," AGOC, March 9, 1999, http://www.gasandoil.com/goc.news/ntc01087.htm. Small volumes of oil from Russia, Turkmenistan, and Kazakhstan are tankered to Iran's Caspian port of Neka and then 'swapped' for equivalent volumes shipped from the Gulf. See USEIA, Country Analysis Brief: Iran, October 2007, http://www.eia.doe.gov/emeu/cabs/iran.html.

30. OPEC, OPEC Annual Statistical Bulletin, p. 31; and House of Representatives, Enforcement of the Iran-Libya Sanctions Act and Increasing Security Threats from Iran, pp. 23-28. 
1991 Gulf War. During November 1998-2002, however, the Ba 'thist regime had expelled weapons inspection teams then monitoring imports of dual-use technology under the 1996-2003 Oil-for-Food program, which permitted Iraq to spend oil revenue on necessities in return for submitting these purchases to inspection and pre-approval within the scope of the weapons monitoring effort. ${ }^{31}$ In this context, the September 11, 2001 attacks on the World Trade Center in New York and the Pentagon in Washington, DC furnished a rationale for the Bush Administration to brand Iraq as part of an "axis of evil" backing terrorism and WMD acquisition and to seek Security Council approval for military intervention later that fall. Secondarily, these events incited a comparison by some think tank scholars of the costs of exporting Iraqi and Azeri crude oil and speculation as to whether the start of BTC pipeline construction had been deliberately moved up to September 2002. ${ }^{32}$

Iraq's energy reserves fueled optimism regarding the country's post-invasion oil production, export, and revenue potential. While the 1972 nationalization of the Iraq Petroleum Company rendered methods of estimating proven oil reserves opaque and corresponding estimates uncertain, even after deducting the 1928-2002 cumulative production of nearly 29 billion barrels, Iraq's actual reserves remained large (at least 78 billion barrels), its production costs low, its territory sparsely explored, only one-fifth of its fields in operation, and only one-quarter of over 500 prospective sites ever drilled, with only $6 \%$ of drilled sites developed. ${ }^{33}$ This propitious combination raised hopes that regime change could improve the investment climate and raise output to six million daily barrels. ${ }^{34}$

However, decades of mismanagement, accumulated debt, war, and sanctions raised the risk of further invasion-related damage to Iraq's oil industry. During the 1980-1988

31. Kenneth Katzman, Iraq: Oil-for-Food Program, International Sanctions, and Illicit Trade (Washington, DC: Congressional Research Service, 2003), p. 3, http://www.fas.org/man/crs/RL30472.pdf.

32. Bulent Aliriza, as cited in Xinhua, "Baku-Tbilisi-Ceyhan pipeline is key to US oil policy," $A G O C$, November 13, 2002, http://www.gasandoil.com/goc/news/ntc24643.htm; and Andreas Andrianopoulos, "The Economics and Politics of Caspian Oil," Journal of Southeast European \& Black Sea Studies, Vol. 3, No. 3 (September 2003), p. 80. Also see footnote 4. In fact, the schedule laid out in the October 2000 Turnkey Agreement between BTC Sponsor Group (MEP Company) and BOTAS, Turkey's state oil pipeline operator and directorate for BTC's Turkish section, implies that the 32month construction phase began two months late, after the July 2002 completion of a 12-month detailed engineering phase. See BOTAS, "Baku-Tbilisi-Ceyhan COPL Project Directorate," http://www. btc.com.tr/eng/project.html and http://www.btc.com.tr/eng/chronoloji.html.

33. Gal Luft, "How Much Oil Does Iraq Have?" Iraq Memo \#16, May 12, 2003, http://www.brookings.edu/papers/2003/0512globalenvironment_luft.aspx; Council of Foreign Relations and James A. Baker III Institute for Public Policy of Rice University (Baker Institute Report), Guiding Principles for U.S. Post-Conflict Policy in Iraq (January 2003), http://www.cfr.org/content/publications/attachments/Post-War_Iraq.pdf, p. 19; USEIA, Country Analysis Brief: Iraq; and OPEC, OPEC Annual

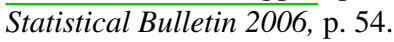

34. Neil Ford, "Iraq: The Crucial Dimension," The Middle East, No. 334 (May 2003), pp. 42-45; and Fadhil Chalabi, "Iraq and the Future of World Oil," Middle East Policy, Vol. 7, No. 4 (October 2000), p. 166. According to the Baker Report, Iraq had a pre-invasion oil production capacity of "between 2.6 and 2.8 million barrels per day." Baker Institute Report, Guiding Principles for U.S. Post-Conflict Policy in Iraq; OPEC, OPEC Annual Statistical Bulletin 2006, p. 11. However, over the course of 2002, Iraq was producing on average only 2.0 or 2.1 bpd. USEIA, Annual Energy Review 2006, p. 309. In January and February of 2003, Iraq's average daily output increased to 2.5 million bpd. IEA, Oil Market Report, April 10, 2003, p. 57 and IEA, Oil Market Report, May 13, 2003, p. 55. 
Iran-Iraq War, the oil terminals and tankers in the Persian Gulf suffered heavy damage and Iraq's export pipeline through Syria was closed. Iraqi oil production was capped below 1.5 million daily barrels and the bulk of its commensurably reduced exports middecade were funneled through the Iraq-Turkey (IT) pipeline to Ceyhan (the capacity of which was augmented in 1984 and again 1987, with the addition of a parallel line). ${ }^{35}$ The Gulf War destroyed a larger swath of the national energy infrastructure, reducing Iraq's southern oil industry to a small fraction of its former capacity in mid-1991, with subsequent UN sanctions shutting down its export pipelines altogether.

The Oil-for-Food program afforded Iraq the opportunity to restore oil output on a sustainable basis. Iraq earned $\$ 65$ billion in revenue from legal oil sales, but was estimated during 1997-2002 to have earned at least \$4 billion (but perhaps upwards of \$21 billion) from illicit exports though Turkey, Syria, Jordan, and the Persian Gulf. ${ }^{36}$ As the 2000-2002 period marked Iraq's brief respite from war, OPEC quotas, or full sanctions, average annual output and exports correspondingly rose by around one-fifth over that three-year period relative to the first half of Oil-for-Food, while Iraq's average annual revenue (peaking at nearly $\$ 20$ billion for 2000 ) nearly doubled. ${ }^{37}$ Revenue was probably misused, as evidenced by such practices as prolonged overpumping prior to the March 2003 war as well as the reinjection of refined oil and unchecked water intrusion into crude reservoirs, all of which degraded the quality of Iraq's higher quality crude blend from Kirkuk and lowered recovery rates there to $9 \%$ and to $15-25 \%$ in the south. ${ }^{38}$

Thus, based partially on the same UN reports of the 'lamentable' state of Iraq's oil industry that led to the 1998-2000 relaxation of oil revenue ceilings, informed observers were inclined to downplay expectations of a bonanza based on "wishful thinking ... that [Iraqi] oil revenues will help defray war costs and the expense of rebuilding the Iraqi state and economy." 39 The Baker Institute Working Group, for example, estimated that restoring and developing Iraq's well infrastructure would cost \$30-40 billion, and that Iraq, having experienced steady yearly output declines before the 2003 conflict, would need 18-36 months as well as $\$ 5$ billion initially and $\$ 3$ billion in subsequent annual operating expenses to repair existing export installations and restore output to its annual pre-1990 peak of 3.5 million daily barrels. ${ }^{40}$

During the March-April 2003 offensive, US-led coalition forces minimized new battle damage to Iraqi oil infrastructure. With Iraqi forces having destroyed roughly 700 wells before their 1991 retreat from Kuwait and possibly mining wells in northern Iraq, US forces, mindful of a similar possibility, acted to secure all but seven of Iraq's 1,500 wells and repair teams quickly extinguished any remaining fires. However, in-

35. Iraq-Turkey Pipeline export percentages are derived by comparing Iraq's overall export volumes found in OPEC, OPEC Annual Statistical Bulletin 2006, p. 31, with Kirkuk-Ceyhan export quantities compiled by BOTAS and reproduced in Table 7.23 of Turkey, State Planning Organization (DPT), "Economic and Social Indicators," http://www.dpt.gov.tr/dptweb/esg/esg-i.html.

36. UN Office of the Iraq Program (UNOIP), "Oil Exports (By Phase)," http://www.un.org/Depts/ oip/background/basicfigures.html; Katzman, Iraq, pp. 12-14; and Judith Miller, "The Oil-for-Food Program: Panel Pegs Illicit Iraq Earnings at \$21.3 Billion,” The New York Times, November 16, 2004.

37. OPEC, OPEC Annual Statistical Bulletin 2006, pp. 13, 21, and 31.

38. USEIA, Country Analysis Brief: Iraq, March 2004, http://www.eia.doe.gov/emeu.cabs/iraq.htm.

39. Baker Institute Report, Guiding Principles for U.S. Post-Conflict Policy in Iraq, p. 10.

40. Baker Institute Report, Guiding Principles for U.S. Post-Conflict Policy in Iraq, pp. 10-13, 16, 19-22. 
surrectionist looting and sabotage - the first waves of resistance at the beginning of the occupation - targeting the country's vast pipeline network and power grid caused almost four-fifths of total infrastructure damage. ${ }^{41}$ Iraqi oil pipelines, installations, and personnel were attacked nearly three dozen times in 2003, with this count quadrupling and reaching its annual peak in 2004 (yearly attacks fell to 79 in 2007). ${ }^{42}$ Consequently, while Iraq earned $\$ 5$ billion in June-December 2003 (\$8.6 billion for the entire year) and another $\$ 16$ billion by December 2004, thus benefiting in part from $\$ 30-40$ per barrel prices helped by its lower exports (Iraqi instability may have added a \$10 per barrel 'security premium'), it suffered respective average output and export shortfalls of almost 900,000 and 450,000 daily barrels compared to pre-war estimates, as well as \$7-21 billion in cumulative revenue losses during 2003-2004. ${ }^{43}$

Oil Production from the Caspian and Iraq (thousand daily barrels)

\begin{tabular}{|c|c|c|c|}
\hline Year & $\begin{array}{c}\text { Azerbaijan and } \\
\text { Kazakhstan }\end{array}$ & $\begin{array}{c}\text { Non-Russian FSU } \\
\text { Caspian }\end{array}$ & Iraq \\
\hline 1997 & 718 & 1,008 & 1,166 \\
\hline 1998 & 768 & 1,088 & 2,121 \\
\hline 1999 & 910 & 1,244 & 2,610 \\
\hline 2000 & 1,026 & 1,347 & 2,614 \\
\hline 2001 & 1,147 & 1,480 & 2,523 \\
\hline 2002 & 1,329 & 1,582 & 2,116 \\
\hline 2003 & 1,424 & 1,792 & 1,344 \\
\hline 2004 & 1,612 & 1,957 & 2,030 \\
\hline 2005 & 1,808 & 2,126 & 1,833 \\
\hline 2006 & 2,080 & 2,368 & 1,999 \\
\hline
\end{tabular}

Source: Authors' calculations based on data found in British Petroleum, BP Statistical Review of World Energy, June 2007, p. 8.

Note: Non-Russian FSU Caspian production figures include Azerbaijan, Kazakhstan, Turkmenistan, and Uzbekistan.

\section{TURKEY, IRAQ, AND PIPELINE CONNECTIONS}

Ankara's interest in an alternative energy transportation route already had become increasingly salient due to post-Cold War increases in 'free' oil transit through Turkey's

41. USEIA, Country Analysis Brief: Iraq, March 2004; and Williams, "Projections for the geopolitical economy of oil after war in Iraq," p. 1078.

42. Pipeline attacks are tabulated by the Institute for the Analysis of Global Security (IAGS), "Iraq Pipeline Watch," http://www.iags.org/iraqpipelinewatch.htm; The Brookings Institution, Iraq Index: Tracking Variables of Reconstruction \& Security in Post-Saddam Iraq, http://www.brookings.edu/iraqindex.

43. Calculations are derived from UNOIP, "Oil Exports;" The Brookings Institution, Iraq Index; and Milan Vesely, "Iraq's Oil Wealth Fuel Fires of Discontent," The Middle East, No. 351 (December 2004), pp. 26-27. On the 'security premium' factored into oil prices, see John Roberts, "The Cost of Iraq Oil,” http://platts.com/Oil/Resources/News\%20Features/iraq/costs.htm. 
narrow Bosphorus Straits as well as post-Gulf War cuts in Iraqi oil supplies and tariff revenue. Until the BTC commenced operation, the vast share of oil exported from Azerbaijan, Kazakhstan, and Russia was reaching the Black Sea ports of Novorossiysk and later Supsa to converge on the Bosphorus. Several thousand oil tankers, most departing from Russian territory, now carry a daily average of 2.4 million barrels (down from over three million barrels). With Turkey having experienced accidents resulting in oil spills in 1994 and 1999, the latter coating $10 \mathrm{~km}$ of shoreline in the environs of Istanbul, Ankara began taking measures that arguably exceeded its rights under the 1936 Montreux Convention, such as requiring tanker operators to use local pilots and banning nighttime transit for ships over a certain length. Augmented and increasingly regulated Bosphorus traffic has effectively lengthened 'demurrage' or delays, charges for which consume up to one-third of the price of transported oil. ${ }^{44}$

Turkey's preference for the BTC was further reinforced by losses of transit revenues and oil imports due to post-1990 shutdowns of the Iraq-Turkey Pipeline. This pipeline bringing oil from Kirkuk to Ceyhan has not worked continuously since its inception in 1977, with the longest interruption spanning August 1990-December 1996. Prior to the imposition of UN sanctions, it pumped at its maximum in the 1980s, reaching a peak average of 1.5 million daily barrels from 1987 (after the second line was completed) until August 1990. Moreover, in these respective periods, Turkey diverted a fraction of this throughput to its own refineries, representing at least $30 \%$ of its total crude oil imports. ${ }^{45}$

Under the aegis of UN sanctions, however, Ankara closed the IT pipeline and stopped trading with Iraq. Revenue from pipeline oil shipments, transit of other goods to Europe, construction contracts, and worker remittances were severed, Iraqi debt repayment suspended, tourism receipts dropped, and oil prices soared due to the four million barrel per day shortage of supplies (including Kuwait's). ${ }^{46}$ Ankara obtained compensation in the form of arms, security assistance (PKK attacks accelerated after the end of the Iran-Iraq War), higher US textile import quotas, and concessionary oil supplies from Saudi Arabia, Kuwait, and the United Arab Emirates. ${ }^{47}$ Moreover, UN Resolution 986 mandated the use of IT as a conduit for "the larger share" of Iraq's oil exports (the normal situation prior to the Gulf War, but characterizing only one year after 1990, which was 1998) and allowed Iraq to exceed its oil revenue ceiling to IT tariff costs for the first three semi-annual phases of Oil-for-Food, while illicit truckborne

44. "Georgian border breached by pipeline," AGOC, February 2, 1999, http://www.gasandoil.com/ goc/news/ntc90660.htm; "Turkey intends to improve navigational safety of Turkish straits," AGOC, March 3, 1999, http://www.gasandoil.com/goc/news/ntc91076.htm; "Bosphorus bottleneck complicates exports of Caspian oil," AGOC, June 29, 2004, http://www.gasandoil.com/goc/news/ntc42617. htm; "Russia seeks alternative to Turkish straits," $A G O C$, September 1, 2004, http://www.gasandoil. $\overline{\mathrm{com}} / \mathrm{goc} / \mathrm{news} / \mathrm{ntc} 43555 . \mathrm{htm}$; USEIA, Country Analysis Brief: World Oil Transit Chokepoints, January 2008, http://www.eia.doe.gov/emeu/cabs/choke.html; USEIA, Country Analysis Brief: Turkey, http://www.eia.doe.gov/emeu/cabs/turkey.html.

45. Derived from DPT and Table 2 in Philip Robins, Turkey and the Middle East (London: Pinter Publishers, 1991), p. 102.

46. Bruce Kuniholm, "Turkey and the West," Foreign Affairs, Vol. 70, No. 2 (Spring 1991), pp. 36-37; and USEIA, Iraq Energy Chronology: 1980-February 2004, http://www.eia.doe.gov/emeu/ cabs/iraqchron.html.

47. Kuniholm, "Turkey and the West," pp. 37-38. 
shipments to Turkey were condoned. ${ }^{48}$ Yet these measures failed to help Turkey recover an estimated $\$ 40$ billion of income lost by 2002 from trade restrictions.

In the wake of the March 2003 invasion of Iraq, grounds for pessimism about jump-starting Iraq's oil industry, especially in terms of restoring IT flow to its pre-1990 heyday, renewed optimism for BTC's prospects. The war brought about a virtual halt to Kirkuk-Ceyhan exports after June 2003, when the IT pipeline was first attacked by Iraqi insurrectionists, whose acts of sabotage, compounding the effects of already poor maintenance originating prior to the invasion, helped to suppress pipeline operations to no more than 100,000 barrels per day on average over the 2004-2007 period (in 2005-2006, the line was pumping no more than 36,000 daily barrels on average). This de facto re-closure limited average Iraqi oil exports to 400,000 daily barrels for 2003 (compared to 1.6 million daily barrels in the last three months leading up to the war) and to less than 1.5 million daily barrels for $2004-2006 .{ }^{49}$ It also has underscored what BOTAS, Turkey's state oil pipeline operator, has emphasized as the benefits Turkey can expect to receive from the BTC: \$150-300 million per year in "transit fees and operations service payments;" lower costs of transporting oil to Turkish refineries (in terms of a 13-day reduction in transit time vis-à-vis oil arriving from the Persian Gulf); and an ability to purchase $30-40 \%$ of the transported oil. ${ }^{50}$ Only in early 2008, after some improvement in security impinging on IT pipeline operations, was Kirkuk oil again reaching Ceyhan at pre-invasion rates; but by then, the BTC pipeline was transporting nearly twice as much oil. ${ }^{51}$

\section{THE IRAQ WAR, THE CASPIAN REGION, TURKEY, AND EUROPE}

As we argued above, contrary to the initial expectations, the war in Iraq gave an unforeseen boost to the financial and political fortunes of projects to export Caspian oil to global markets. These projects encompass natural gas as well. Just as the extraction of larger volumes of Caspian oil and gas became more economically feasible in a seller's market, so did the pipelines to export them. If the building of the seminal BTC pipeline seemed far-fetched in the 1990s, many additional projects have either been completed (e.g., the Baku-Tbilisi-Erzurum and the Turkey-Greece leg of a larger planned Turkey-Greece-Italy Internconnector) or are under active consideration (e.g., Nabucco and the Trans-Caspian pipelines). ${ }^{52}$

Indeed, as instability in the Middle East dragged on, major energy consuming countries began to pay more attention to the Caspian basin. Among them, European nations have had more reason - namely, uncertainty regarding Russian control of

48. Katzman, Iraq, pp. 2, 7, and 14.

49. BOTAS, "Crude Oil Transportation Activities and Facilities;" UNOIP, "Weekly Oil Exports under the United Nations Oil-for-Food Programme," http://www.un.org/Depts/oip/background.oilexports.html; and OPEC, OPEC Annual Statistical Bulletin 2006, p. 31.

50. BOTAS, "Baku-Ceyhan-Tbilisi COPL Project Directorate."

51. BOTAS, "Crude Oil Transportation Activities and Facilities."

52. For more information on these projects, see Ali Tekin and Paul Williams, "Europe's External Energy Policy and Turkey's Accession Process," Europe-Asia Studies, forthcoming, as well as Ali Tekin and Paul Williams, “Turkey and EU Energy Security: The Pipeline Connection," East European Quarterly, Vol. 42, No. 2 (June 2008). 
major sources of natural gas - than other actors to prioritize access to the Caspian's energy resources. Although companies from Europe have been important players in the region's energy sector, the EU and its member states have developed strong interest in the Caspian only in recent years. The EU has labelled the Turkey-Greece-Italy Interconnector and Nabucco pipelines as "Trans European Networks-Energy priority projects" because it considers these projects significant steps in ensuring the transit of energy resources and the increased security of supply in Europe.$^{53}$

A particularly important means for Europe to reach Caspian energy resources is the Nabucco Pipeline Project, construction of which is expected to start in 2009. The project will have the capacity to convey assorted Caspian and Middle Eastern sources of natural gas, amounting to yearly volumes of up to 30 billion cubic meters, across Turkey to Europe, where Bulgaria, Romania, Hungary, Austria, and possibly France will transport or consume a share of the piped gas. ${ }^{54}$ The project has run into difficulties, as state-owned Hungarian and Austrian member companies of the Nabucco Consortium agreed with Gazprom to undertake rival joint ventures in transportation and storage projects. In addition, the project may founder on Turkey's resistance to including Gaz de France, whose home country has staunchly opposed the former's EU accession, as a seventh member of the consortium. ${ }^{55}$ Yet EU diplomacy, including a recent visit to Turkey by Commission President Jose Manual Barroso, has been trying to ameliorate the situation in the interests of expediting the project. ${ }^{56}$

Turkey also has emerged as a more central presence in the energy realm. While the Iraq War was expected to worsen economic losses for Turkey, it helped the country in unexpected ways. Other than improvement in the economic feasibility of trans-Turkey pipeline routes due to high energy prices, assessments that the Caspian, Central Asia, and Iran hold enough gas to supply Europe through Turkey at reasonable costs helped to establish Turkey as a natural transit route to Europe. Therefore, coupled with heightened European interest in non-Russian sources of gas, which is commmonly transported via pipelines (unlike oil), higher energy prices increased Turkey's strategic value for Europe. ${ }^{57}$

Recent events are indicative of these new developments. In June 2007, a highlevel Istanbul conference examined the common challenges and opportunities for the EU and Turkey in the energy field. A joint statement of Turkish and Commission leaders called the conference "a milestone in their strategic cooperation in the field of energy," emphasizing the importance of strategic cooperation and exploitation of Turkey's geographic location in enhancing energy security for Europe. Firm commitment was extended to Nabucco and other projects with the goal of exploiting Turkey's potential

53. Commission of the European Communities, "The Community Guidelines for the Development of the Trans-European Energy Networks," Decision 1364/2006.

54. Tekin and Williams, "Turkey and EU;" and Tekin and Williams, "Europe's External Energy."

55. On these and what this and similar projects imply for Turkey-EU relations, see Tekin and Williams, "Europe's External Energy;" and Ali Tekin and Iva Walterova, "Turkey's New Geopolitics: The Energy Angle," Middle East Policy, Vol. 14, No. 1 (Spring 2007).

56. See for example, Enis Berberoglu, "Barroso'nun gazı var" ["Barroso Has Gas”], Hurriyet, April 13, 2008.

57. On Turkey-EU relations in general, see Ali Tekin, "Future of Turkey-EU Relations: A Civilisational Approach," Futures, Vol. 37, No. 4 (May 2005). On Turkey's renewed strategic value in general, see Tekin and Walterova, "Turkey's New Geopolitics: The Energy Angle." 
to become a major energy player. ${ }^{58}$

The conference also clearly linked Turkey's role in European energy security with its accession process. After affirming Turkey's strategic importance for the security of energy supplies to the EU, the joint statement declared that, "as Turkey is moving forward in the accession process, coherent policies will need to be implemented with a view to ensuring secure access to the energy resources of the region and their safe arrival to the markets." ${ }^{59}$ The statement also encouraged Turkey to join the Energy Community as soon as possible, "as an equal party in the decision making process." 60

Generally more supportive of the development of Caspian energy resources and their export to Western markets via Turkey (rather than Russia or Iran), American policy did not change much after the Iraq War. The US has encouraged EU countries to follow more active policies in the region. ${ }^{61}$ However, Iran remains a crucial point of contention. While the EU is generally more sympathetic to the option of bringing more Iranian gas to Europe through the Nabucco pipeline, the US remains a vehement opponent. Thus, short of major regime change in Iran, the Nabucco project is not likely to include Iran, even if this compromises its ability to bring sufficient quantities of gas to Europe.

\section{CONCLUSION}

Like any complicated engineering undertaking that bears the added burden of crossing geologically and politically difficult countries, the BTC pipeline project faced numerous setbacks until it became operational in 2006. Contrary to initial expectations, the war in Iraq failed to kill the BTC because it could not unleash a flood of cheap Iraqi oil. In addition to its having gained considerable endogenous momentum from the last half-decade of generally rising oil prices as well as from a number of other unforeseen economic and organizational developments, the selection of the BTC was favorably influenced by Azerbaijan's and Turkey's respective security problems affecting the aging Baku-Novorossiysk and Kirkuk-Ceyhan lines. The geostrategic calculations of successive US presidents also ensured the success of the BTC, less via their ambivalent stance towards trans-Russian oil exports than by way of veto over the trans-Iranian route and, even more inadvertently, through inadequate provision for the security of Iraq's oil infrastructure.

Besides boosting the financial and political status of the BTC, the Iraq War also has lent a helping hand to other projects connecting Caspian energy supplies with outside markets, especially European ones. As instability in the Middle East has continued, energy prices have soared, reinforcing Russia's moves to tighten state control over Eurasian energy supplies, so the EU and its member states have begun to view the Nabucco project as more vital to Europe's energy security. This project, which has been complicated by considerations of whether or not to include Iran, brought together Caspian energy suppliers, Turkey, the EU, and — to a great extent — the US around a broadly consistent common energy policy regarding the Caspian basin. This has happened, however, not as part of a conscious design, but rather as an unanticipated outcome of the war in Iraq.

58. Joint Press Release, Turkey and the EU: Together for a European Energy Policy — High Level Conference in Istanbul on June 5, 2007, http://europa.eu/rapid/pressReleasesAction.do.

59. Joint Press Release, Turkey and the EU.

60. Joint Press Release, Turkey and the EU.

61. See David Gow, “US Tells Europe to Stop Dithering Over Pipeline,” The Guardian, February 23, 2008. 